\title{
12
}

\section{POWER OF PLACE AND LANDSCAPE}

\section{The US 10th Mountain Division, from Colorado to the Apennines}

\author{
John M. Scott
}

\section{Introduction}

This chapter presents and compares three military landscapes ${ }^{1}$ encountered by the United States (US) Army's Second World War 10th Mountain Division² (the Division), the only wartime US formation dedicated to mountain warfare. The Division was primarily trained in the Colorado Rocky Mountains and had (selfdescribed) good luck and success in the contested northern Apennine Mountains of Italy in 1945. The focus of this study is a fieldwork-based comparative investigation of the Division's Rocky Mountain training landscape and two sections of its Italian Campaign battle-zone landscape, Riva Ridge and Hill 913. ${ }^{3}$ The Division's training centre at Camp Hale (the Camp) in the Colorado Rockies was a harsh, high-elevation mountain landscape, and at an elevation of 2,750 metres above sea level (ASL), was mostly more difficult to navigate and manoeuvre in than the 700 to 1,500 metres (ASL) of their Italian battle-zone landscape - the last defensive line of German military occupation in the northern EmiliaRomagna Apennine Mountains, from December 1944 to early April 1945.

The Division's training in the Rocky Mountains was more than adequate for their task of scaling mountain heights at the centre of the German Wehrmacht ${ }^{4}$ Gothic Line in 1945. However, during combat, the Division suffered many casualties. ${ }^{5}$ German weaponry clearly took its toll, but two well-known habits of the Division played a role: they were known for not turning back and they always held their ground (Isserman 2019: 16). Fortunately, these combat mountaineers had the benefit of being fresh to battle from two years of training in Colorado. They could also tap into combat experience and intelligence gained by the Allies during their attacks on Axis forces in Italy over the preceding 16 months. They benefited too from aerial photography and real-time combat updates from the Allied air forces that controlled their battle-zone airspace. ${ }^{6}$ 
Their mountain combat training, aided by the local inhabitants of the EmiliaRomagna Apennines, helped the Division move up to the front lines and ascend what the Germans considered impassable mountain winter landscapes to attack fortified German communications and observation posts on 18 February 1945. In combat, by early March 1945, the Division had taken 20-30 kilometres of mountains and hills and was considered a seasoned combat infantry, understanding the battle-zone landscape as well as any veteran combat unit. Later that spring, the Division was chosen to lead the American 5th Army out of their winter encampment (Imbrie and Imbrie 2004: 19), and on 14 April they attacked and took Hill 913.

Prior to the arrival of the Division, the Nazis had forced the Italian mountain inhabitants to construct the Gothic Line in the northern Apennines. These defences were built of strong points constructed on high ground commanding killing-zones created by mutually supporting machine guns, mortars, artillery, and mines. Global Navigation Satellite System (GNSS) data recently obtained during fieldwork on one of these high points, Hill 913, is presented and interpreted below.

\section{Military landscapes and signs}

This study is concerned with the military landscapes of specialized mountain training and mountain battle-zones. It proceeds from the view that landscapes are not just a material concept (Head 2010: 427) but exist also as memories which can be recalled to navigate physical as well as social landscapes. Generally, the physical landscape, or its symbols and signs, prompts the recall, but a memory of landscape can be triggered by any stimulus. Human repetitive interaction in physical and social landscapes strengthens and maintains people and their identity. Identity and culture (including military training) shape human perception and give meaning to the physical world with which people must interact. Landscape and culture are thus dialectically connected by feedback that creates and maintains perception. Military training is in many instances based on this type of mental imprinting and information exchange (Burchell 2019 this volume).

Signs and symbols associated with and found within the landscape are rarely universal; their meanings are culturally, contextually, and temporally determined. The reading of symbols and their association with landscape can be controlled because people often need to be trained to understand them. Thus, knowledge of the landscape can be used to inform or dominate others (Tilley 1994: 26). In contrast to the slow construction of memories and identity through normal daily life, the Second World War rapidly created new landscapes, with millions killed and wounded, and huge amounts of material produced and destroyed in a short time. Second World War battle-zones were intended to be deadly and confusing, and the Division was specially trained to recognize signs of danger and death in the cold and steep mountains, and how to react to them. In the Division's battle-zone landscape, buildings and travel routes could mean ambushes, snipers, machine gunners, 
mines, and explosive traps, or helpful noncombatant inhabitants, and sometimes both. To conquer the occupying forces, the soldiers had to pass through a series of deadly landscapes that quickly became peopled by the dead and wounded.

\section{Power of place}

The 10th Mountain Division developed a cohesion and group identity based on shared experience, and an intensive training regime in the high mountain landscape of central Colorado. That process mirrored Tilley's 'power of place' (1994: 26), where landscapes encountered in daily life through interaction with material and people and used in communication are invested with power or are seen as possessing power. People develop special meanings and symbols to understand and to be able to approach powerful landscapes such as mountains. In the case of the Division, the soldiers' intense daily training regimen, their isolation in the mountains, and their constant review by peers and trainers acculturated them to combat in this specific landscape in a short period of time.

The power of the mountain includes its height above the surrounding terrain, its ruggedness and slope, and this can be accentuated by the elements of elevation, darkness, and weather. Controlling the mountaintop or the high terrain gave soldiers a ground advantage over those below (Isserman 2019: 185); for much of the Second World War, the Germans had high ground advantage across the mountains of Italy. This facilitated easy observation of the battlezone and allowed weapon fire to be directed downwards on enemies struggling to manoeuvre upwards. German mountaintop defences encountered by the Division were powerfully constructed to occupy a particular position within a blocking defence system. ${ }^{7}$ The Germans also had a more comprehensive view of and thus more control over the contested space. Mountaintops, therefore, can become a source of power and a place to be contested (see Cornish [this volume] for the analogous military importance of crest lines at lower altitude).

\section{Training landscapes of the Camp}

Camp Hale in Colorado (Figure 12.1) is located in the sparsely occupied Eagle Park along US Highway 24. Historically, this wide area of the Eagle River's valley bottom was known as Pando Valley, lying at an elevation of 2,800 metres, and characterized by potentially dangerous weather conditions for eight months of the year. It lies within a historic mining and railroad landscape surrounded by the towns of Red Cliff, Gilman, and Leadville. The Camp is a federal protected historic site listed on the National Register of Historic Places. It also, however, similar to modern battlefields, remains dangerous due to hazardous material dumps and unexploded ordnance. Above and south of the Camp, a granite monolith listing the names of 1,000 Division soldiers killed has been erected on Tennessee Pass at the entrance to the Division's original ski training area, now the Ski Cooper resort. 


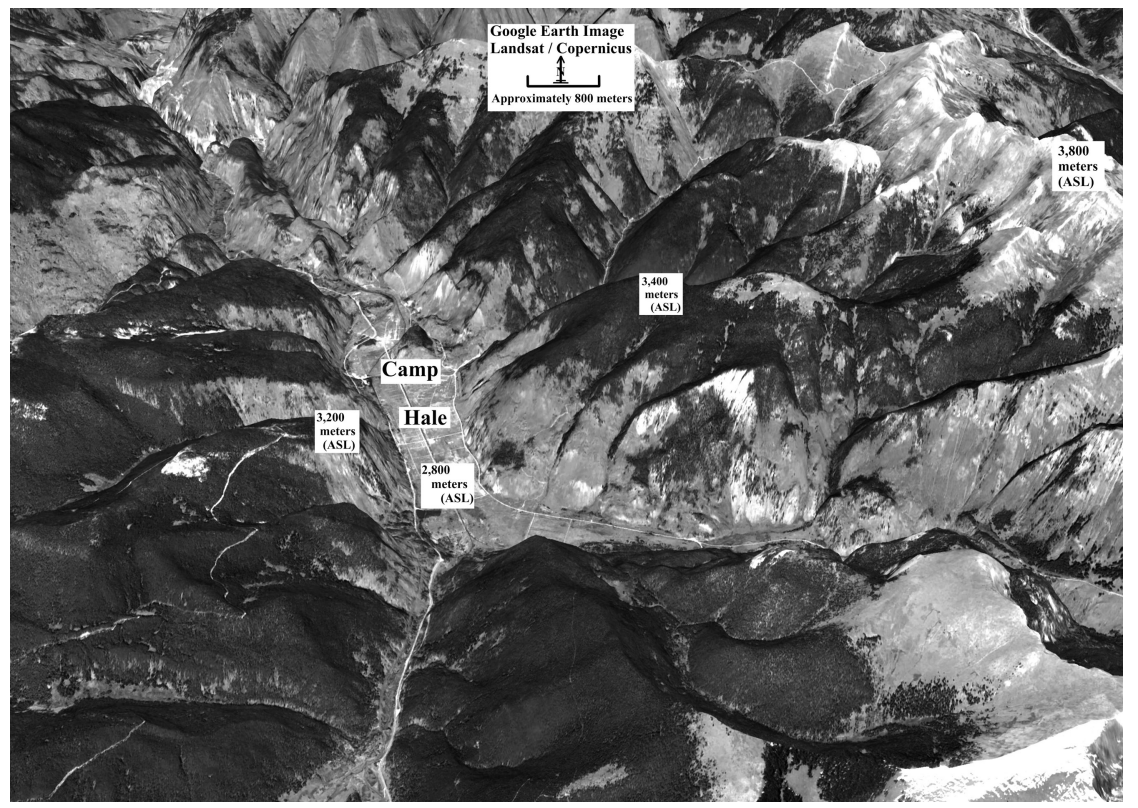

FIGURE 12.1 Google Earth oblique view of Camp Hale's central training area consisting of the Pando Valley floor and the immediate surrounding mountains. Source: (C) Google Earth Landsat/Copernicus.

The Camp was the equivalent of a small city, and essentially a wartime experiment to build a specialized infantry 'weapon', the 10th Mountain Division (Isserman 2019: 33). From 1942 to 1945, the Camp was the US centre of mountain combat training. At the time, it was considered ultra-modern due to the speed at which it was designed and built into the 'hazardous' mountain landscape and for its unique training facilities. When completed, it was well equipped with the capacity to house up to 20,353 mountain infantry trainees and with facilities for conducting basic training and combat mountaineering (Rottman and Dennis 2012: 10; Witte 2015: 46). At the time, it was the largest construction project undertaken in Colorado (Witte 2015), and once completed, the Camp's population peaked at nearly 17,000 soldiers and trainees (Rottman and Dennis 2012: 10).

\section{Constructing a military landscape}

In early 1942, the Pando Valley saw the construction of a contractor's camp, housing 10,000 workers. Between April and November 1942, civilian workers levelled the valley, straightened the Eagle River, and erected about 1,000 predesigned wooden and a few concrete buildings (Isserman 2019: 66). These would eventually house 16,800 individuals, stable approximately 4,000 horses 
and mules (Witte 2015: 81), and kennel about 200 dogs (Jenkins 2003: 51). Training facilities included a 457-metre-long rifle range, anti-aircraft weapon ranges, and several smaller ranges for pistol, grenade, machine gun, ${ }^{8}$ and bayonet. Combat ranges for urban terrain as well as ranges utilizing zigzag trenches were also available. Rock faces for technical climbing were within walking distance at nearby higher and more difficult locations. Small downhill ski runs with rope tows were available at the Camp with a larger ski area about 300 metres higher in elevation just minutes away by vehicle. A short-lived artificial 'glacier' was also constructed nearby (Witte 2015: 85). ${ }^{9}$ A soldier was able to step out of the Camp barracks and begin skiing at 2,800 metres and could traverse upward to as high as 3,660 metres; more rugged mountains reaching 4,270 metres were accessible beyond these lower mountains.

\section{Recruits}

Training at the Camp was conducted by American and international world-class mountaineers, skiers, and arctic explorers who were experienced in conquering mountains and cold landscapes. The National Ski Patrol (NSP) was involved from the beginning, and the Army made them the primary recruiter for the Division. Mountain experience or other types of outdoor experience with three letters of recommendation were initially required. The Army also ordered that the first recruits should be 18-19-year-old Colorado skiers and climbers (Witte 2015: 77-78). Out of 12,000 applications, the NSP eventually recommended 7,000-8,000 recruits (Isserman 2019: 40). Thus, more than half of the trainees knew something about mountain landscapes and had an alpine lifestyle in common prior to arriving at the Camp in 1942.

At the time, most ski racers and coaches were at northwestern and northeastern universities and colleges. This meant that many initial recruits had college degrees, making the Division one of the most highly educated US Army infantry units (Isserman 2019: 61). After recruitment of the initial 7,000 to 8,000 NSPendorsed volunteers, more men were needed to fill the Division and recruitment was opened to general enlistment. The Army, not the NSP, recruited the remainder of the unit. Many of these later Army recruits were not able to ski or climb; they found the training and location miserable. From December 1942 to June 1944, the training dropout rate reached 55\% (ibid.: 102).

All who completed training were changed physically and mentally by the regime and the landscape. At high elevation, becoming physically fit requires individuals to be properly acclimatized because intensive physical training at elevation can have deleterious physiological and psychological effects. ${ }^{10}$ However, there is at least one known benefit of such training, and that is a temporary improvement of physical performances at lower elevations (Levine 2016). Although these advantages eventually diminish, trained individuals know that the lack of oxygen (hypoxia) while conducting intensive activities, whether at high or low elevation, can be overcome. 


\section{The D-Series at Camp Hale}

The Camp was the only training location where the entire Division (all three regiment $\left.{ }^{11}\right)$ manoeuvred together as a single combat mountain unit of approximately 13,000 soldiers. The Army conducted this manoeuvre known as the 'Division-Level Series', or D-Series, to measure the ability of the three regiments to operate together in mountain combat simulations. During the D-Series, the Division, with a thousand mules, manoeuvred in simulated combat on steep terrain up to 3,960 metres in elevation during temperatures of 30 to 35 degrees below zero in nearly a metre of new snow during day and night (Isserman 2019: 129-133).

For three weeks in March and April 1944, the Division was pushed to its limits with minimal equipment and at times skiing continuously for up to 18 hours in extreme weather to reach their high mountaintop bivouac at 3,700 metres (Feuer 2006: 3). During the test, officers lost their soldiers; the location of entire regiments was at times unknown; and supplies were not delivered. Soldiers absent without leave (AWOL) numbered in the hundreds and had to be rounded up by military police from a nearby town (Isserman 2019: 130-131).

The Army declared the Division had proven itself and survived a worst-conditions scenario. Many of the graduates of the D-Series did not see the results in the same way. ${ }^{12}$ They felt that they had barely survived, considering 195 cases of frostbite and 340 incapacitating injuries (ibid: 133). Several soldiers' memoirs and accounts (e.g. Dusenberry 1991; Whitlock and Bishop 1992: 42-44; Witte 2015: 175-182) recall that when combat in Italy became especially horrific, the soldiers would often say, 'yea it's bad, but not as bad as the D Series', or 'if this gets any worse, it's gonna be as bad as D-Series' (Witte 2015: 189). Notably, the D-Series was conducted on colder, higher, more expansive terrain than any of the ridges that the Division would eventually capture in Italy.

\section{Mountain battle-zone landscape}

When large military formations, such as a division, engage in combat on mountain landscapes, it is inevitable that they break into smaller elements because of limited usable ground surface, limited manoeuvrability, and limited communications. Mountain strongpoints are sought after because they provide a better view of the battlefield and control more space than they occupy. Line of sight and other forms of communication connect such points to each other to form a dynamic system of defence, which the Germans adopted against the Division. Combat units of company and platoon size were used by the Division to successfully attack both Riva Ridge and Hill 913.

At Riva Ridge, the Germans were unaware that the US Army had any substantial mountain combat capabilities, and so put too much faith in the steep and harsh landscape. Reinforcing this mistaken view was that no such specialized forces had been used in any of the three previous failed American attacks on Riva 
Ridge and Monte Belvedere. In addition, American soldiers laying communication wires advanced up the ridge close behind their attacking units, providing critical communication between front line fighters and rear command. At Hill 913, however, sniping, booby traps, and mines quickly broke down the attacking American units, and forward momentum was maintained not by communication with rear command but by the initiative, bravery, and skill of a few soldiers.

More broadly in this context, civilian and military landscapes merge in battle-zones, and many multi-vocal overlapping accounts are produced at different times during, before, and after conflict, stimulated by confusion, fear, and trauma. In this sense, a conflict landscape is always in motion and in a process of becoming (Bender 2001: 4). Over time, art and monuments are created to memorialize the battle and the people, and these works are also manifestations of the different perceptions constructed during and after the conflict. Places, monuments, signs, and symbols evoke memory and emotion, and due to the interest of multiple stakeholders, they can become troubled and contested (Zalewska et al. 2017: 14). The Apennines of Emilia-Romagna offer a contemporary example of this. Interpretive signs at historical Division locations have been vandalized (Figure 12.2). Some signs providing information about local Italian resistance to the war have been damaged, with words and plaques scratched out, perhaps stemming from changing and conflicting interpretations of what Italian resistance fighters represented and accomplished (and see De Nardi 2017). In other words, signs as material culture are as volatile as the landscapes they announce.

\section{0th Mountain Division battle-zone landscape}

The 10th Mountain Division was one of the last combat units sent to the Italian Campaign, arriving in Naples in the winter of 1944-1945, itself heavily bombed due to being the principal Allied supply port (Ellis 1996: 99). Several soldiers described their arrival and paint a dramatic picture of sunken ships, bombedout factories, piles of rubble, and broken and strafed walls and buildings. The Neapolitan poor were ever-present and consisted mostly of children and teenagers (Cossin 2001: 20).

Just prior to the Division's departure for Italy, on 6 November 1944, the US Army officially designated it the 10th Mountain Division. ${ }^{13}$ However, on entering Italy their identity was kept secret: they told no one who they were and wore no identifying symbols or shoulder patches (Cousins 2001: 21). By mid-February, the entire Division had secretly moved to the frontlines of the US 5th Army by various routes, including a 28-kilometre march through un-reconnoitred snowy mountain terrain at night. In the 5th Army's front lines, they were positioned with the 442nd Infantry (composed of Japanese-Americans) about 40 kilometres to their left with rugged mountains between them. Within about three to four kilometres to their right was the Brazilian Expeditionary Force (BEF) and the all-black US 92nd Infantry, known as the Buffalo Soldiers. The Division was billeted in local homes and public buildings and allowed out only at night. 


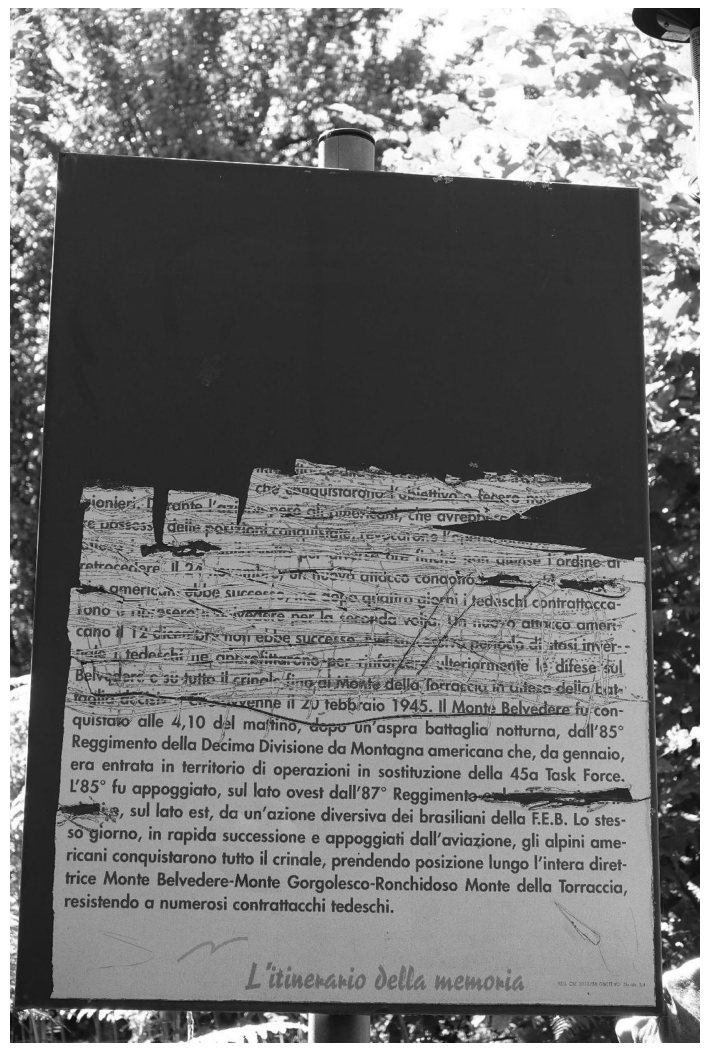

FIGURE 12.2 Interpretative sign on Monte Belvedere. Information on the Partisans has been removed from the upper half, and information on the Germans has been scratched out near the centre. Information on the Division is largely intact. Source: (C) and courtesy of Kelly J. Pool.

The soldiers developed a camaraderie and friendship with the gente di montagna on the front lines in the Emilia-Romagna Apennines in February of 1945. These locals had been living in a social landscape of terror created by the Nazis' commercial construction companies and the Wehrmacht, who were planning, building, and occupying the German Gothic line. Forced labour and terror were the German Army's tools to control rebellion and force compliance, and for that reason, since September of 1944, civilian areas in Italy outside of fascist control had supported Allied efforts to defeat the Nazis and Italian fascists (Jennings 2016: 117-120). Several murders and massacres were committed by the German Army in retaliation for partisan attacks within the Division's battlezone. Memorializing the victims of these atrocities, the administrative regions of Lizzano in Belvedere and Gaggio Montano in the Emilia-Romagna Apennines have erected monuments and plaques. 


\section{Riva Ridge and Monte Belvedere}

The Division arrived at the front lines and led the limited action known as Operation Encore with the support of the Allied BEF and the US 92nd Infantry in reserve. This operation was to secure better positions for the planned Allied 1945 spring offensive towards the Po River Valley. Hill 913, discussed below, was part of the Division's battle-zone and a divisional objective, and consequently became one of many warscapes created and etched into divisional memory during the spring advance of 1945.

On the night of 18 February 1945, the Division prepared for their first attack, which would be the night ascent of Riva Ridge and then Monte Belvedere. On their front in the mountains to the north, they were opposed by troops of the Infanterie Regiment 232 (Isserman 2019: 137). In an irregular-shaped mountain bowl formed by three high ridges (Figure 12.3), the Division's soldiers were positioned with their backs to Monte Grande on the south; they faced the Germans on the north along all the high ground of the 5.6 kilometrelong Serriccia-Campiano Ridge line, designated as "Riva Ridge"14 and along the Belvedere-Torraccia Ridge. Riva Ridge (Figure 12.4) was an observation and communications post that controlled the German forward slopes of Monte Belvedere (Figure 12.5). A much more strongly defended mountain to the northeast, Monte Belvedere, was the southwestern-most peak of the southwest/

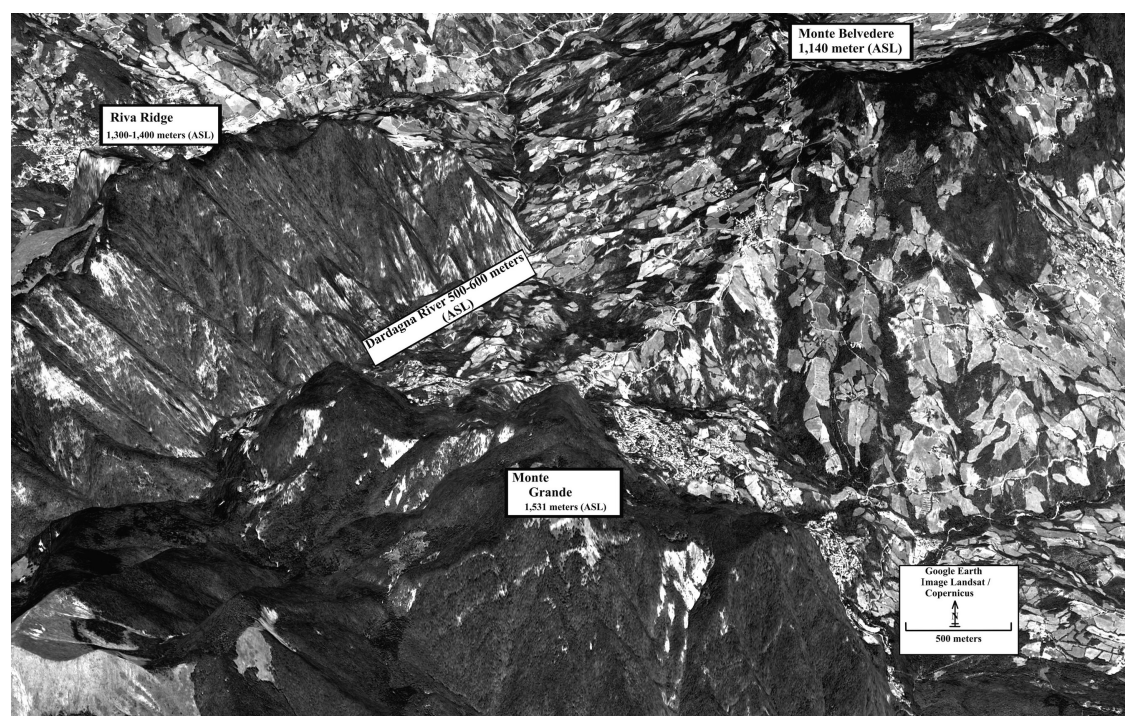

FIGURE 12.3 Google Earth oblique view northwards of the irregular-shaped mountain bowl with Riva Ridge on the northwest, Monte Belvedere on the northeast, and Monte Grande on the south. The Division's five attack routes on 18 February 1945 ascended Riva Ridge's southeastern slope. Source: C) Google Earth Landsat/Copernicus. 


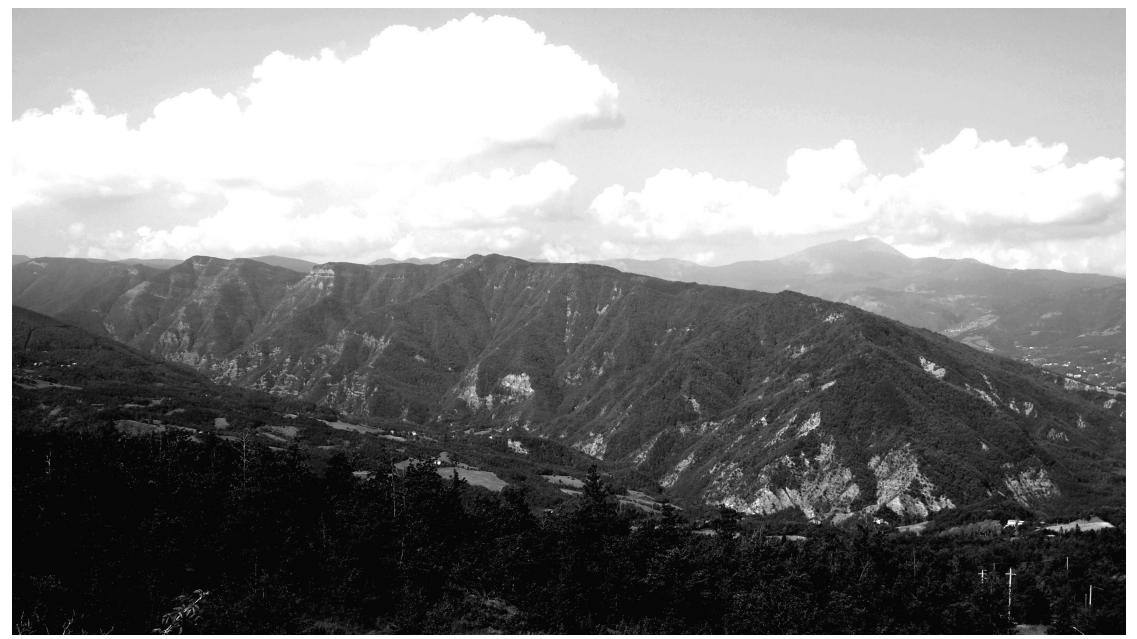

FIGURE 12.4 View looking west at Riva Ridge from Monte Belvedere. Source: (C) author.

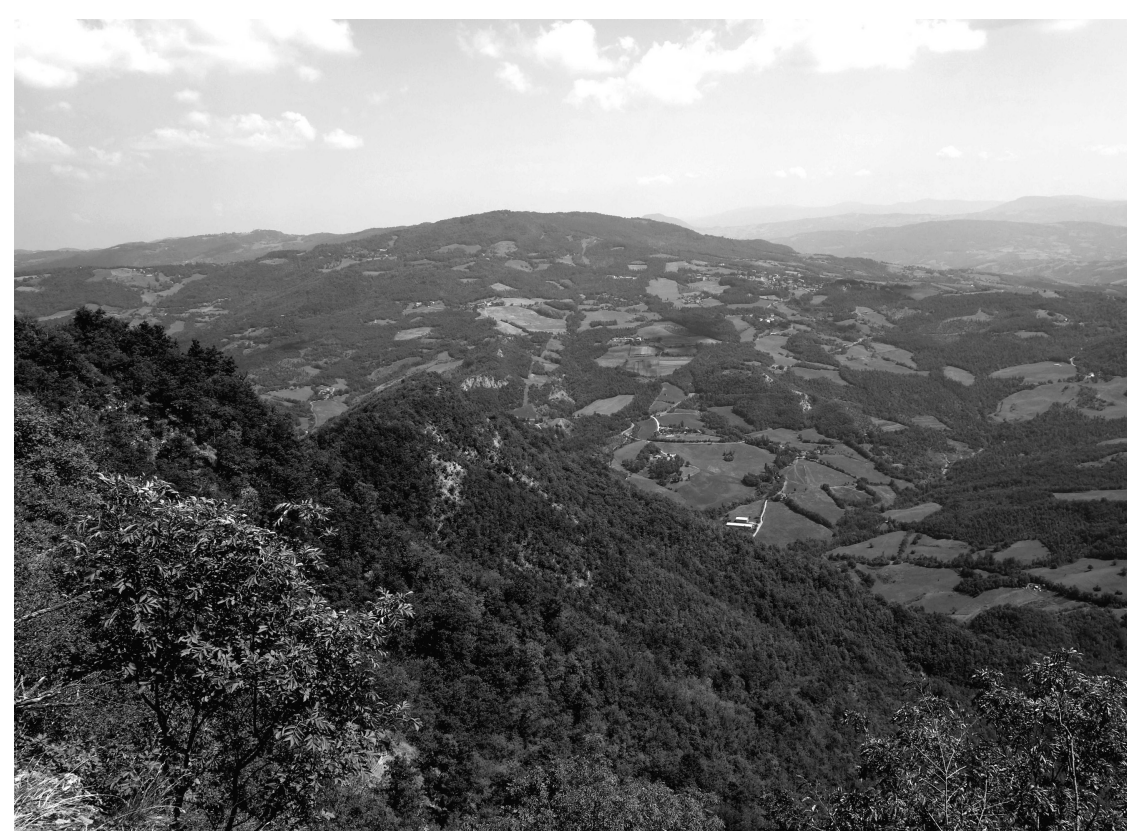

FIGURE 12.5 View looking east at Monte Belvedere from Riva Ridge. Source: (C) author. 
northeast-trending Belvedere-Torraccia Ridge line. The German defensive system here epitomized the layout and organization of the deadly landscape that the Division encountered throughout the northern Apennines. The German Army controlled the high points and defended them with a concept of 'defence in depth', consisting of natural landscapes, built barriers, minefields, explosive traps, hidden snipers, and plunging fire from machine guns, mortars, and artillery.

Riva Ridge was less fortified than Monte Belvedere because the Germans believed its steep icy cliffs facing south towards the American lines protected the ridge-top from attack. The Germans were confident of their defences because the two ridges had already been assaulted unsuccessfully by Allied forces on three separate occasions. In preparation for the new attack, part of the Division moved under cover of night to the base of Riva Ridge and waited in the narrow valley of the Dardagna River. Riva Ridge above was a frozen finger-like mountain range with multiple snowy peaks and a river flowing below. The majority of the rest of the Division was hidden at the southwestern base of the slightly lower and less steep Monte Belvedere, about five kilometres east of Riva Ridge. All this high ground was occupied by Wehrmacht soldiers supported by their Gebirgsjäger - specialist mountain troops - who knew they were about to lose the war but nevertheless continued to fight from their high ground, manning machine guns, mortars, and artillery from behind ubiquitous barbed wire and mines.

At Riva Ridge, soldiers of the Division conducted one of the most daring mountain combat actions of the war. Weeks prior to the attack, Division climbers had secretly reconnoitred and selected five routes up the 2,000-foot-high (610 metres) ridge that they would use for their night attack. One of the few landscape advantages the Division's mountaineers had over the German troops entrenched above them was that they were fighting about 1,850 metres below the elevation of Camp Hale; they fought below that elevation for the rest of their combat in the Apennines. Unintimidated by the elevation and slope of these Italian mountains, the Division's soldiers were at one with their landscape.

In approximately ten hours of climbing (equivalent to a day's training at Camp Hale), the Division's mountaineers led several groups of more than 700 soldiers armed with small arms and hand grenades up the steep ice and snowcoated cliffs of Riva Ridge, immediately below German outposts. Two of the five routes required pitons and ropes. Conducted overnight, the surprise assault was completely successful, taking all enemy positions, and defending against all counterattacks. ${ }^{15}$ Significantly, the defeat of these German counterattacks saw the Division triumph over some of its direct counterparts in the German Army, the Gebirgsjäger battalion, attached to Infanterie Division 232. ${ }^{16}$ With German observers thus ejected from Riva Ridge, the rest of the Division could begin their uphill assault on Monte Belvedere and Monte Gorgolesco the following night. The Division broke the German mountain defences and, moving northeast, knocked them out until 6 March 1945; from then until 14 April, they regrouped and occupied the village of Castel d'Aiano and the high ground of Monte della Spe. During that time, they patrolled and probed their front, and 
prepared for the Allied spring advance to drive into the Po River Valley on 14 April.

\section{The 1945 spring breakout and Hill 913}

The first three days of the spring offensive (14-16 April 1945) were the worst of the war for the Division, with 1,336 casualties. On 14 April, Companies I, K, and L of the 85th Mountain Regiment on Monte della Spe had Hills 883 and 913 as their primary objectives and began their combat day watching the Allied air force bomb these and other hills to their north. Following the bombing, a 35-minute artillery and mortar barrage concentrated on the companies' main objectives, Hills 883, and 913, blanketing the area with smoke and dust. By the time Company L began their mid-morning advance across the valley separating Monte della Spe and Hill 913, most of the artillery smoke had dissipated. They took Hills 883 and 913 the same day.

Hill 913 was intensively mapped in 2019 as part of our fieldwork because it is a well-preserved example of the organization and layout of a Second World War German mountain defence (Figure 12.6). The data adds physical evidence to the historical documentation of the Division's battle-zone and training landscape. Our preliminary mapping results indicate that on the hilltop and around its slopes there are as many as 100 features associated with the Division's 14-15 April 1945 actions which captured it. Included here is Bunker A, a rectangular deep depression measuring approximately nine metres long, five metres wide, and five metres deep (Figure 12.7); four linear communication trenches - three averaging 20 metres long and one nearly 40 metres long - all terminating in circular pits at the south-facing slope edge; at least four U-shaped depressions likely representing mortar positions; and a mix of about 75 rectangular, circular, or irregularly shaped depressions representing artillery, mortar, and bomb hits, fox holes, and other unidentified combat features encircling the hilltop (Figures 12.6 and 12.8). When combined with historical documentation, these data from Hill 913 provide a detailed plan of the layout and organization of a specific German strongpoint within the Gothic Line battle-zone. Zones of fire and supporting minefields can be accurately determined and explored, and accounts of individual soldiers can be traced across today's landscape.

The German positions encountered by the Division at Hill 913 were similar to the 'Mountain Defence' diagrammed by Bull and Noon (2013: 28-29), and their information was used to interpret the GNSS-mapped features of Hill 913. ${ }^{17}$ The mountain defence at Hill 913 (Figure 12.6) can be interpreted as consisting of forward slopes running down from the hilltop that contained isolated forward observers, snipers, and hidden machine-gun nests. The forward slopes were a German-controlled no man's land; patrols from both armies entered and exited this area, probing each other's defences and collecting intelligence. German machine guns were dug into the high point, just back from the forward slope's edge. On the rear slope, bombproof bunkers (Bunkers A and B in Figure 12.6; 


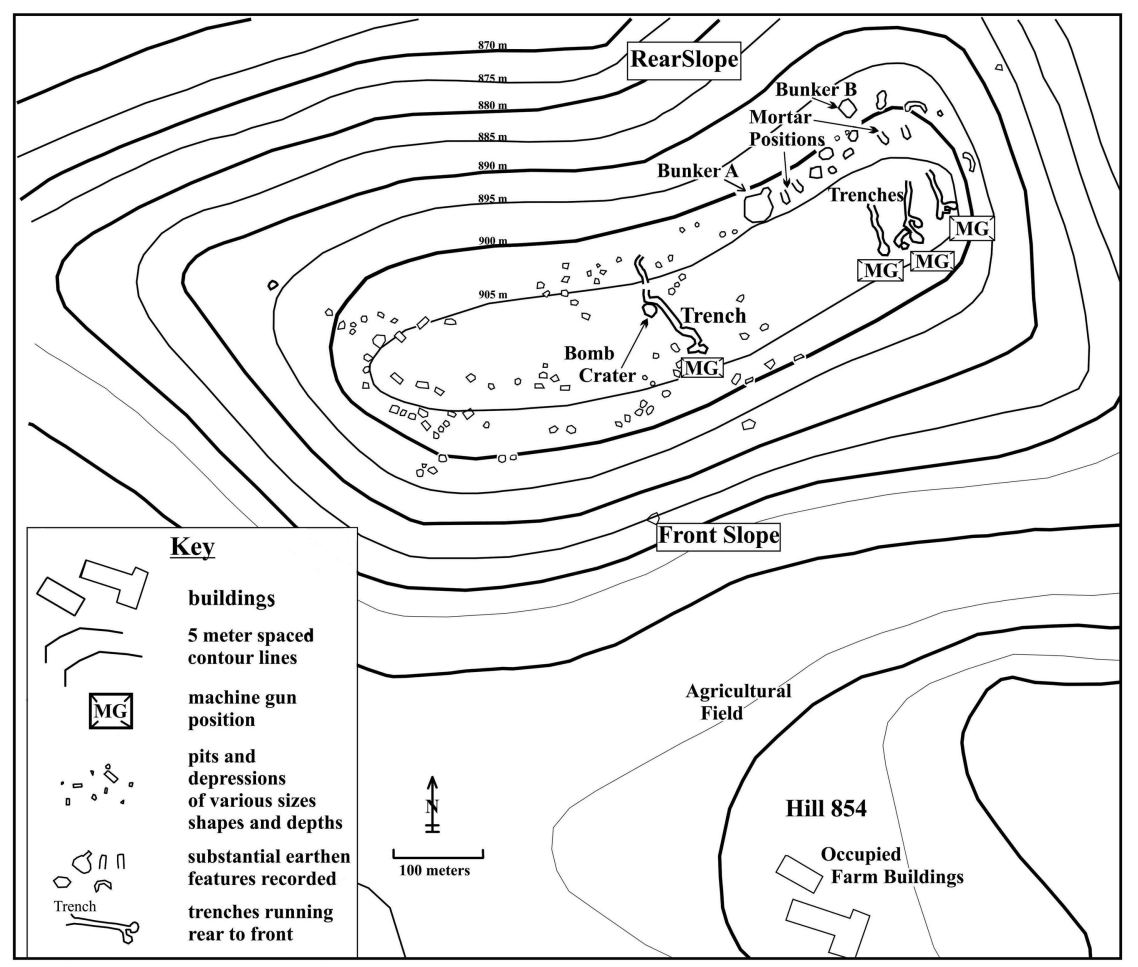

FIGURE 12.6 GNSS-produced sketch map of Hill 913 showing the defences. Soldiers of the Division attacked from the south and west, and the former had to capture Hill 854 first. Source: (C) author.

Bunker A in Figure 12.8) were constructed with communication trenches connecting them to the machine-gun pits at the front slope. Mortars and (most likely) artillery were also positioned in this rear area, and in combat, they concentrated arched plunging fire onto or beyond the front slope towards the enemy.

The Division's standard manoeuvre to defeat these strong points was to attract fire by attacking the German front slope. While the main body held fire to the front, one or more soldiers tried to flank the German position, attacking from the side. However, this type of attack in the Apennines had to coordinate with other forces advancing on the surrounding hilltop strongpoints to disturb and distract overlapping defensive fire. As part of the battle-zone landscape at Hill 913, the Division's John Magrath was awarded the Medal of Honor (posthumously) in part for successfully conducting this flanking manoeuvre at Hill 909 immediately east of Hill 913 on 14 April.

There are extensive first-person accounts as well as many military records that can be used to interpret the landscape of the Hill 913 battle-zone. However, the portion of the battle-zone presented in Figure 12.8 follows descriptions 


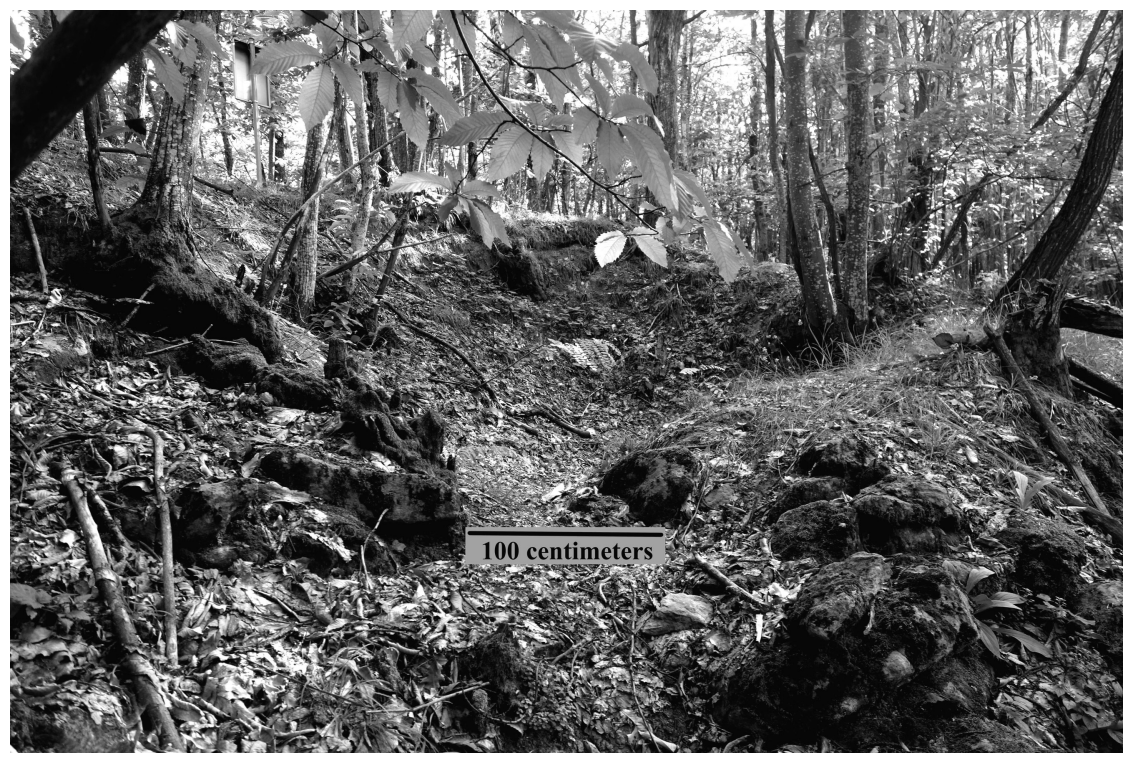

FIGURE 12.7 View southwest of the remains of Bunker A on the rear (north) slope of Hill 913. In the foreground, boulders line a 100-centimetre-wide path and the scale marks the bunker's entrance. Source: (C) author.

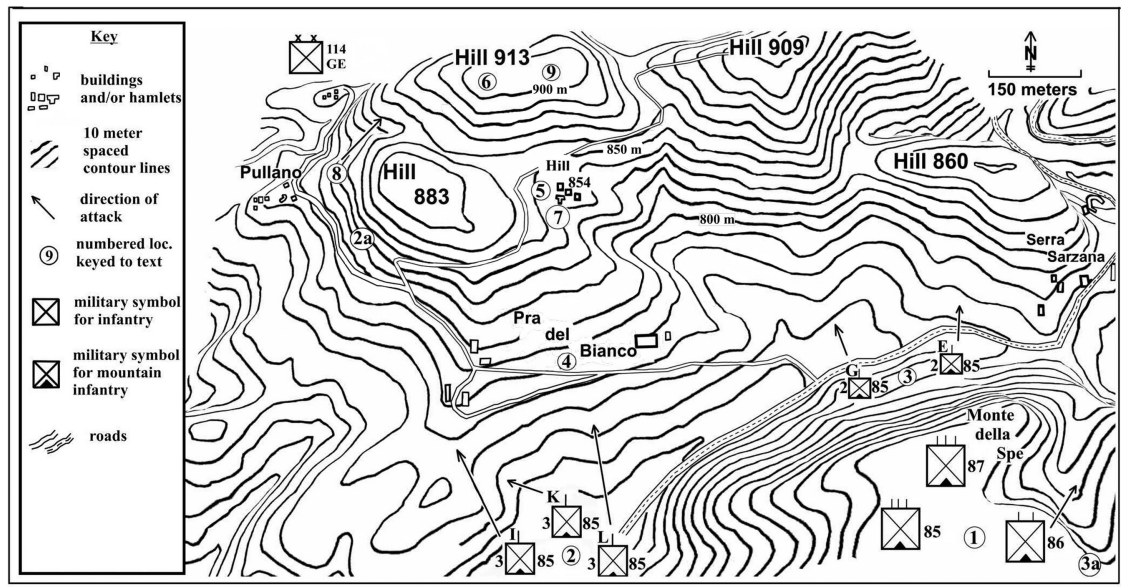

FIGURE 12.8 The Hill 913 battle-zone landscape on 14 April 1945. The Division (shown with military symbols) occupied Monte della Spe and confronted German-occupied Hills 883, 913, 909, and 860. The German 114th Infantry Division is shown as a military symbol upper left. Source: (C) author. 
provided in the Division's history (Imbrie and Imbrie 2004), the 85th Mountain Regiment's history (Woodruff 1945), and W. Putnam's first-hand account (1991: 120-132).

\section{Hill 913 conflict landscape}

The following list of numbered points refers to locations in the landscape of the Hill 913 battle-zone presented in Figures 12.6 and 12.8.

1) Military symbols representing the Division's three mountain regiments of the 85th, 86th, and 87th on 14 April 1945 occupying the high point of the Hill 913 battle-zone, Monte della Spe.

2) Military symbols representing the three Companies I, K, and L (3rd Battalion, 85th Mountain Regiment) at mid-morning, coming from the west side of Monte della Spe to attack north towards Hill 913. L is to attack the front slope of Hill 913 via Pra del Bianco, a sloping agricultural field.

a) I followed by $\mathrm{K}$ are to attack the left (west) approach of Hill 913 via Hill 883 and the hamlet of Pullano. Tanks that are supposed to support I, K, and L are delayed due to mines to the south (not shown). I and K continue to be stalled on the southwest slopes of Hill 883 because of steep terrain and minefields.

3) Military symbols representing Companies $G$ and $E$ of the 2nd Battalion of the 87th Mountain Regiment at the base of Monte della Spe on 14 April ready to attack hills 860 and 909 at the same time as I, K, and L attack hills 883 and 913.

a) Elements of the 86th Mountain Regiment will attack to the northeast towards Rocca Roffino.

4) A platoon from $L$ becomes pinned down in the Pra del Bianco near an eastwest trending road and agricultural field. The field is mined, and machinegun fire from above has stopped them. Lieutenant Putnam arrives and rallies a few other soldiers upward towards farmhouses on Hill 854 below Hill 913. This group of soldiers is later followed by others from the pinned-down platoon to the farmhouses.

5) A firefight occurs at the farmhouses, and several German soldiers surrender with Italian civilians also present. The German prisoners agree to go to the top of Hill 913, with Putnam calling out for other Germans to surrender.

6) As the Americans and their prisoners reach the top of Hill 913, dozens more Wehrmacht soldiers surrender. At the same time, the US Army begins shelling the hill, and American and Wehrmacht soldiers shelter together in a bunker (Bunker A, Figure 12.6). The shelling stops and the few Americans and their prisoners withdraw to the buildings at Hill 854. Later the Americans 
return in force and occupy Hill 913, taking additional prisoners and remaining in control, under German artillery shelling.

7) By mid-morning, most of L Company have arrived at Hill 854 but I company is still 183 metres from Hill 883. Tanks remain stalled by mines.

8) At mid-afternoon, I Company is depleted due to casualties from minefields and machine-gun fire as they try to move up the southwest slope of Hill 883. K moves through I's position, making it onto the left flank of Hill 913 by late afternoon. Shortly thereafter, some American tanks arrive on the west flank of Hill 913, but others are still slowed by the large minefield on that slope.

9) At dusk, Hill 913 is occupied by K and L. By night, all the tanks have reached Hill 913. Hills 883 and 913 are occupied and held that night by several American companies. During this action, several thousand mines are removed from Hill 913.

\section{Conclusion}

There are several important differences between the conflict landscapes of the Camp in the Rocky Mountains and the Division's battle-zone in the Apennine Mountains. First, of course, Camp Hale was a facsimile battle-zone with no combat casualties. Second, as assessed during fieldwork, the Camp is a federally protected and administered historic site, while the Division's Italian battle-zone sites are officially unprotected due to the absence of Italian heritage laws governing landscapes, sites, and material culture from the Second World War. Despite this, the sites are generally well signposted and their material now professionally curated, identified, and interpreted by local private and community interests at the Monti della Riva and Iola di Montese museums. These actions have created several new contemporary landscapes - a partly cleared, partly annotated, but still undocumented battle-zone, and a new museological landscape. It is worth commenting that while the facsimile landscape of Camp Hale is protected by law, the real battle-zone landscape (with all its national, political, and emotional aspects) has no recognition or protection - the simulacrum appears more valued than the authentic.

Third, the Camp and its Rocky Mountains training landscape are both higher than the Division's actual battle-zones in the Apennines. The slopes of Riva Ridge, however, are actually steeper than that of the Pando Valley's east mountain slope (Figure 12.9) used daily for training at the Camp. The Rocky Mountain landscape actually prepared the American mountain soldiers to manoeuvre in a terrain that was more difficult than the one which confronted them in the Apennines. The only mountaineering skills needed by the Division in the Italian Campaign were for ski patrols conducted in the vicinity of their front when they first arrived, and for the Riva Ridge attack. However, of the five routes used in the Riva Ridge attack, only two required climbing equipment (Isserman 2019: 168). By the time the Division led the Allies' spring breakout in 1945 and 


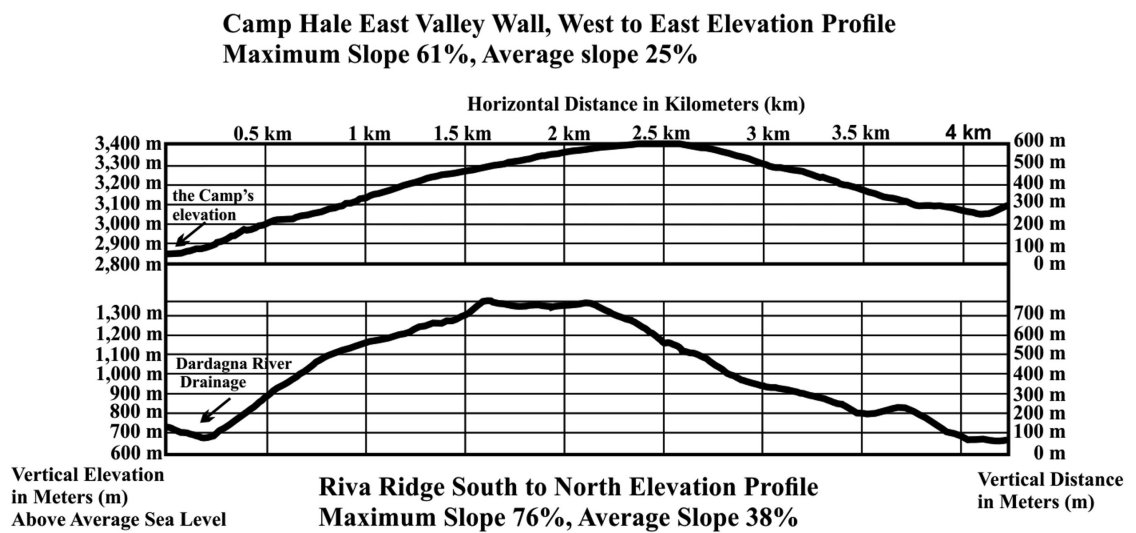

FIGURE 12.9 Graphs drawn from Google Earth elevation profile data for the westfacing mountain slope of Camp Hale and the southeast-facing mountain slope of Riva Ridge. Source: (C) Google Earth data; graph by author.

captured Hill 913, they were basically common infantry soldiers with no need for mountaineering skills.

Nevertheless, the relationship between these soldiers and their conflict landscapes was deeply formative, physically and psychologically. It was the intensity of their training and enculturation regime in the Rocky Mountains that allowed the US Army to create efficient specialized mountain infantrymen able to mount a successful operation in their designated terrain almost 'straight off the boat'. This was achieved despite the US Army having no tradition of mountain warfare - unlike their German opponents, particularly the Gebirgsjäger who counterattacked at the Riva Ridge. The 10th Mountain Division retained their dynamic identity after their mountain victory, successfully leading the US 5th Army into the Po River Valley.

\section{Acknowledgements}

I would like to thank Marco Belogi, Susan Daniels, Andrea Gandolfi, Amy Nelson, Kelly Pool, Massimo Turchi, Susan van Dyck, and John Winterburn. They all helped me map and map onto the landscape of the 10th Mountain Division in the Apennine Mountains of Emilia-Romagna, Italy.

\section{Notes}

1 The term 'military landscape' acknowledges the association between training sites and areas which saw fighting. Saunders and Cornish (2009: 5) use the term 'battlezone landscapes' for the First World War. Anthropologically, 'landscape' is commonly understood as a physical presence (i.e. the environment) and the socially and experientially constructed lives of people created from and within their environment. 
These two aspects are in constant flux, and some investigators have argued for a more open-ended understanding of landscape, time, and space (Bender 2002). Landscape in this view is much more reflexive and reflective of social interaction and social knowledge than it is of the physical world, and the creation of various spaces and places by people are shaped and informed by the past and are continually renegotiated and redefined (Bender 2001, 2002; Tilley 1994). Military landscapes therefore are not only those of fighting, but also of memorialization and heritage.

2 The Second World War 10th Mountain Division was established and deactivated during that conflict. Surviving data makes clear the unusual nature of this highly trained, well-motivated, and (initially) civilian-inspired formation. The 10th Mountain Division of the twenty-first century is an all-terrain, all-theatre formation, connected to the original division only by the fact that it honours it by employing its name.

3 The fieldwork project, Archaeology of the Night Climb: The Material Culture and Conflict Landscape of the 10th Mountain Division, is a research consortium of Metcalf Archaeological Consultants, Inc. (USA), and the Iola di Montese and Monti della Riva museums of Italy.

4 The regular army of Germany during the Second World War.

5 Rottman and Denis (2012: 41) state that in 114 days of combat the Division suffered 4,086 combat casualties, including 952 dead. They calculated that the Division had $30 \%$ total casualties.

6 Aerial photography was provided by the Allied Mediterranean Airforce in 1945. Currently, the remaining photographs and negatives for Italy are stored in the "National Collection of Aerial Photography (NCAP), Edinburgh, GB [sic]; Aerofototeca Nazionale, Rome, Italy; Centre C. Jullian, Aix-en-Provence, France. The original negatives, partially preserved by NCAP and National Archives and Records Administration (NARA), are currently being digitized by NCAP' (M. Belogi, personal communication, 17 February 2020). The limited archival information currently available online from NCAP includes no Division areas.

7 For a strongpoint to be truly effective, it must be part of an integrated system (Hill and Wileman 2002: 138).

8 In the 1983 Colorado OAHP site plan (White River National Forest Archive), there are four machine-gun ranges facing the cantonment's west valley wall, each having approximately 400 metres of narrow target range. Presumably, somewhere in the training area beyond the Pando Valley in the higher mountains, there were areas for longer-range target firing for machine guns.

9 According to Witte (2015), this was created by spraying water on the mountain side, and ice features such as 'seracs and crevasses' were constructed using logs and steep terrain coated with ice. The glacier would not stay frozen and was eventually abandoned.

10 Most effects of high elevation stem from poor sleep, likely due to difficulty in breathing, which causes daytime drowsiness. Acute mountain sickness (exposure to low oxygen at elevation causing headaches, nausea, sleeplessness, and dizziness) is the most common adverse neurological effect, with high-altitude cerebral oedema the most severe (swelling of the brain causing an extreme headache, disorientation, and lethargy).

11 A US Army Infantry Division of this period comprised three infantry regiments (each of three battalions), and further units providing artillery support, reconnaissance, transport, engineering, etc. An infantry division has three to five battalions, a battalion three to four companies, a company three to four platoons, a platoon three to four squads, and a squad six to ten riflemen.

12 The rigours of the D-Series hit divisional morale, which dropped even lower when, in May 1944, it was rumoured that the formation would be disbanded, though by November the Army had changed its mind again (Putnam 1991: 78-81). Morale remained low when the Division was transferred to Texas for training on lowland terrain, and only recovered when it embarked for Italy at the end of 1944. 
13 Up to this time (i.e. from 15 July 1944), the unit had been called the 10th Light Division (Pack, Alpine) (Rottman and Dennis 2012: 18).

14 Isserman (2019: 157) infers that military intelligence renamed it Riva Ridge after a high point in the same Serriccia-Campiano Ridge line.

15 The mountaineers eventually placed .30- and .50-calibre machine guns, 60-millimetre mortars, and a 75-millimetre mountain howitzer (delivered by mule) on the ridge-tops, ensuring they could hold the position.

16 Sources vary as to the precise identity of this unit, which was either Hochgebirgsjäger Lehr-Bataillon Mittenwald or Hochgebirgsjäger Bataillon 4. As both units were attached to Infanterie Regiment 232, it is quite possible that men of both units were involved in the counterattacks.

17 Interpretive signs are present on the hill, but they provide only broad information about the attack.

\section{References}

Bender, B. (2001) Introduction. In B. Bender and M. Winer (eds.), Contested Landscapes, Movement, Exile and Place, pp. 1-18. Oxford: Berg. (2002) Time and Landscape. Current Anthropology 43 (4): 103-112.

Bull, S. and S. Noon (2013) World War II Winter and Mountain Tactics. Oxford: Osprey Publishing.

Burchell, M.A. (2019) Decoding a Royal Marine Commando: The Militarized Body as Artefact. London: Routledge.

Cossin, C.V. (2001) I Soldiered with America's Elite 10th Mountain Division of W.W.II. USA: First Books.

De Nardi, S. (2017) The Poetics of Conflict Experience: Materiality and Embodiment in Second World War Italy. London: Routledge.

Dusenberry, H. and W. Ware (1991) Ski the High Trail, World War II Ski Troopers in the High Colorado Rockies. Portland: Binford and Mort.

Ellis, R. (1996) See Naples and Die, A ski Trooper's World War II Memoir. Jefferson: McFarland and Company.

Feuer, A.B. (2006) Packs On! Memoirs of the 10th Mountain Division in WWII. Mechanicsburg: Stackpole Books.

Head, L. (2010) Cultural Landscapes. In D. Hicks and M. Beaudry (eds.), The Oxford Handbook of Material Culture Studies, pp. 427-458. Oxford: Oxford University Press.

Hill, P. and J. Wileman (2002) Landscapes of War: The Archaeology of Aggression and Defence. Gloucestershire: Tempest Publishing.

Imbrie, J. and B. Imbrie. (Comps) (2004) Chronology of the 10th Mountain Division in World War II, 06 January - November 1945. International Skiing History. https:// skiinghistory.org/chronology-10th-mountain-division-world-war-ii (accessed 31 December 2019).

Isserman, M. (2019) The Winter Army. The World War II Odyssey of the 10th Mountain Division, America's Elite Alpine Warriors (Kindle Edition). Boston: Houghton Mifflin Harcourt.

Jenkins, M. (2003) The Last Ridge. New York: Random House.

Jennings, C. (2016) At War on the Gothic Line, Fighting in Italy, 1944-1945. New York: Thomas Dune Books (St. Martin's Press).

Levine, B. (2016) How High-Altitude Training Can Benefit Elite Endurance Athletes Like Runners and Swimmers. University of Texas Southwestern Medical Center. https:// utswmed.org/medblog/high-altitude-training/ (accessed 10 January 2020). 
Putnam, L. (1991) Green Cognac, The Education of a Mountain Fighter. New York: AAC Press.

Rottman, G. and P. Dennis. (2012) US 10th Mountain Division in World War II. Oxford: Osprey Publishing.

Saunders, N.J. and P. Cornish. (2009) Introduction. In N.J. Saunders and P. Cornish (eds.), Contested Objects: Material Memories of the Great War, pp 1-10. London: Routledge.

Tilley, C. (1994) A Phenomenology of Landscape: Places, Paths and Monuments. Oxford: Berg Publishers.

Whitlock, F. and B. Bishop (1992) Soldiers on Skis, A Pictorial Memoir of the 10th Mountain Division. Boulder: Paladin Press.

Witte, D.R. (2015) World War II at Camp Hale, Blazing a New Trail in the Rockies. Charleston: History Press.

Woodruff, J. (1945) History of the 85th Mountain Infantry Regiment. skitrooper.org. www.skitrooper.org/85.pdf (Accessed 31 December 2019).

Zalewska, A., J.M. Scott and G. Kiarszys (2017) Introduction: Materiality of Troubled Pasts. Archaeologies of Conflicts and Wars. In A. Zalewska, J.M. Scott and G. Kiarszys (eds.), The Materiality of Troubled Pasts Archaeologies of Conflicts and Wars, pp. 11-20. Warsaw: Department of Archaeology, Szczecin University, Roadside History Lessons Foundation. 